\title{
PENGEMBANGAN MODEL EMISI GAS BUANG KENDARAAN BERMOTOR KOTA DENPASAR
}

\author{
Ir. Dewa Putu Punia Asa. MT \\ Dosen STTD \\ Jl. Raya Setu No. 89, Bekasi \\ Telp./Fax : (021) 8254640
}

Adi Susanto, SH, MH

Dosen STTD

Jl. Raya Setu No. 89, Bekasi

Telp./Fax : (021) 8254640

\author{
Bayu KusuMo Nugroho, M.T. \\ Staf Poltrada Bali \\ Jl. Batuyang No.109 X, \\ Batubulan, Sukawati, Gianyar \\ Telp./Fax : (0361) 291103
}

\begin{abstract}
Air pollution has a negative impact on human health due to pollutants released by motorized vehicles. Of the several types of pollutants produced include $\mathrm{CO}$ and $\mathrm{HC}$ for gasoline-powered vehicles and opacity for diesel-fueled vehicles. The issue of exhaust emissions originating from motorized vehicles is an air pollution problem which is an environmental issue.

The purpose of this study was to determine the effect between years of production (age), the level of vehicle maintenance and fuel supply technology on the level of motor vehicle exhaust emissions produced using multiple linear regression analysis.

From the tests conducted on the model with the F test (simultaneous siji / simultaneous) with a significance value of 0.05 , it indicates that there is at least one variable that affects the emissions produced. T-test results (partial) of the three variables entered affect the emissions produced. The influence of the three variables analyzed affected $80.1 \%$ of the $\mathrm{CO}$ gas produced, $69.2 \%$ of the HC gas produced, and $69.4 \%$ of the opacity.
\end{abstract}

\section{Keywords: Gas Emissions, Linier Regression}




\begin{abstract}
ABSTRAKSI
Pencemaran udara memberi dampak negatif bagi kesehatan manusia akibat polutan yang dikeluarkan oleh kendaraan bermotor. Dari beberapa jenis polutan yang dihasilkan antara lain adalah CO dan HC untuk kendaraan berbahan bakar bensin dan opacity untuk kendaraan berbahan bakar solar. Permasalahan emisi gas buang yang bersumber dari kendaraan bermotor merupakan masalah pencemaran udara yang menjadi isu lingkungan hidup.

Tujuan dari penelitian ini adalah untuk mengetahui pengaruh antara tahun produksi (umur), tingkat perawatan kendaraan dan teknologi suplai bahan bakar terhadap tingkat emisi gas buang kendaraan bermotor yang dihasilkan menggunakan analisis regresi linier berganda.

Dari pengujian yang dilakukan terhadap model dengan uji $\mathrm{F}$ (siji simultan/serentak) dengan nilai signifikansi 0,05 menunjukkan bahwa paling tidak ada satu variable yang berpengaruh terhadap emisi yang dihasilkan. Hasil uji t (parsial) ketiga variabel yang dimasukkan berpengaruh terhadap emisi yang dihasilkan. Pengaruh ketiga variabel yang dianalisis berpengaruh sebesar 80,1\% terhadap gas CO yang dihasilkan, 69,2 \% terhadap gas HC yang dihasilkan, dan $69,4 \%$ terhadap opacity.
\end{abstract}

\title{
Kata Kunci : Emisi Gas Buang, Regresi Linier Berganda
}

\section{PENDAHULUAN}

Transportasi merupakan bagian yang sangat bernilai dan diperlukan saat ini dalam mendukung perkembangan kemajuan kota-kota besar di dunia, namun pada sisi lain peningkatan ini juga sekaligus akan membawa efek negatif yang tidak diinginkan. Peningkatan jumlah kendaraan di Negara Eropa sebanding dengan peningkatan jumlah emisi yang dihasilkan yang merupakan ancaman bagi kesehatan manusia (Hickman, 1999).

Merujuk Undang-undang Republik Indonesia Nomor 22 Tahun 2009 tentang Lalu Lintas dan Angkutan Jalan di bagian kedua yang berisi tentang 
pencegahan dan penanggulangan dampak lingkungan lalu lintas dan angkutan jalan pada pasal 210 dan 211, juga menyebutkan bahwa setiap kendaraan bermotor yang beroperasi di jalan wajib memenuhi ambang batas emisi gas buang dan tingkat kebisingan serta setiap pemilik dan/atau pengemudi kendaraan bermotor dan perusahaan angkutan umum wajib mencegah terjadinya pencemaran udara. Hal tersebut tertuang juga pada Peraturan Pemerintah Nomor 55 Tahun 2012 Tentang Kendaraan pasal 143, yang ditegaskan juga dalam Peraturan Menteri Perhubungan Nomor 133 Tahun 2015 Tentang Pengujian Berkala Kendaraan Bermotor pasal 4, menyatakan jenis kendaraan yang diwajibkan untuk melakukan uji berkala baru terbatas pada kendaraan penumpang umum, mobil bus, mobil barang, kereta tempelan dan kereta gandengan sedangkan kendaraan pribadi dan sepeda motor belum wajib uji. Selain sebagai alat pemantau kelaikan jalan kendaraan, peranan PKB (Pengujian Kendaraan Bermotor) diharapkan mampu mendukung terciptanya udara yang bersih yaitu dengan uji tipe dan berkala kendaraan bermotor.

Permasalahan emisi gas buang yang bersumber dari kendaraan bermotor merupakan masalah pencemaran udara yang menjadi isu lingkungan hidup yang perlu mendapat perhatian. Pengendalian pencemaran udara di wilayah Kota Denpasar telah menjadi suatu wacana penting dalam peningkatan kualitas hidup masyarakat. Pencemaran udara bila dilihat dari dari sumbernya ada tiga kategori yaitu sumber bergerak (misalnya akibat kegiatan transportasi), sumber tidak bergerak (misalnya akibat kegiatan industri dan kebakaran) dan sumber gangguan (misalnya kebisingan dan kebauan).

\section{Tujuan Penelitian}

Tujuan dari penelitian penelitian tentang Pengembangan Model Emisi Gas Buang Kendaraan Bermotor Kota Denpasar adalah:

1. Mengetahui pengaruh antara tahun produksi (umur), tingkat perawatan kendaraan dan teknologi suplai bahan bakar terhadap tingkat emisi gas buang kendaraan bermotor yang dihasilkan. 
2. Mengetahui strategi seksi keselamatan pengujian kendaraan bermotor Kota Denpasar dalam mengendalikan kendaraan bermotor wajib uji yang emisi gas buang melebihi ambang batas di wilayah Kota Denpasar

\section{Metodologi Penelitian}

Penelitian ini dilaksanakan dengan mengambil data di Unit Pelaksana Teknis Pengujian Kendaraan Bermotor Kota Denpasar. Dari data tersebut kemudian diolah dan dianalisis dengan perangkat lunak komputer spss. Secara garis besar alur penelitian dapat dilihat pada Gambar 1.

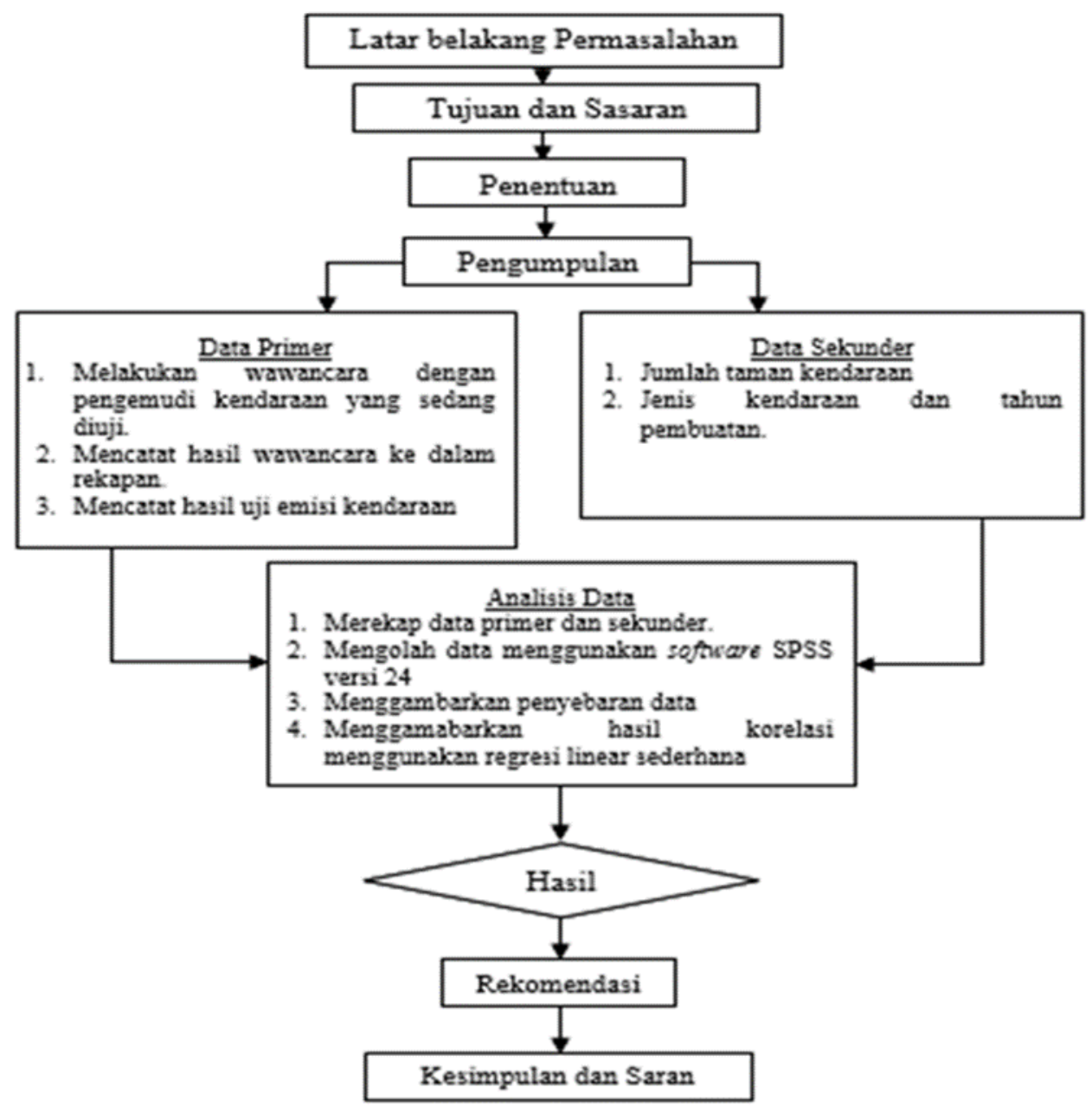

Gambar 1 Bagan Alir Penelitian

analisis data yang dilakukan pada penelitian ini dilaksanakan secara berurutan, yaitu: 
1. Untuk mengetahui hasil pengujian emisi gas buang untuk kendaraan bermotor wajib uji sebagai bagian dari uji berkala kendaraan bermotor dipergunakan alat uji Gas Analyser (bensin) dan Smoke Tester (solar), data hasil pengujian emisi gas buang akan dianalisis mengggunakan statistik deskripsi.

2. Untuk megetahui pengaruh antara tingkat perawatan kendaraan bermotor teknologi suplai bahan bakar (karburator dan injeksi) terhadap tingkat emisi gas buang kendaraan bermotor yang dihasilkan, mengetahui pengaruh antara umur kendaraan terhadap terhadap tingkat emisi gas buang yang dihasilkan, dipergunakan analisis statistik inferensia dengan bantuan software SPSS versi 24.

3. Untuk mengetahui strategi seksi keselamatan pengujian kendaraan bermotor Kota Denpasar dalam mengendalikan kendaraan bermotor wajib uji yang emisinya melebihi ambang batas dipergunakan regresi linear berganda.

\section{REGRESI LINIER BERGANDA}

Regresi linear berganda berguna untuk mencari pengaruh dua atau lebih variabel bebas (predictor) atau untuk mencari hubungan fungsional dua variabel predictor atau lebih terhadap variabel kriteriumnya. Dalam proses pemilihan faktor emisi gas buang terdapat perbedaan pandangan terhadap faktor mana yang paling dominan yang berpengaruh terhadap emisi gas buang yang berkaitan dengan aktivitas transportasi. Dalam memperkirakan faktor-faktor apa saja yang paling berpengaruh digunakan persamaan regresi linier berganda, yaitu:

$$
\mathrm{Y}=\mathrm{a}+\mathrm{b} 1 \mathrm{X} 1+\mathrm{b} 2 \mathrm{X} 2+\ldots .+\mathrm{bnXn}(2)
$$

Dimana :

$$
\begin{array}{ll}
\mathrm{Y} & : \text { Emisi gas buang kendaraan bermotor } \\
\mathrm{X} 1, \mathrm{X} 2, \ldots ., \mathrm{Xn} & : \text { Faktor-faktor emisi gas buang } \\
\text { b1, b2, ..., bn } & : \text { Koefisien dari faktor-faktor emisi gas buang } \\
\text { a } & : \text { Faktor yang tidak terperhitungkan/nilai sisa }
\end{array}
$$


Tabel 1 Pengkodean variabel kendaraan berbahan bakar bensin

\begin{tabular}{|c|c|c|c|c|}
\hline No & & Variabel & Nama Variabel & Kode \\
\hline \multirow[t]{2}{*}{1} & \multirow{2}{*}{$\begin{array}{l}\text { Variabel } \\
\text { Terikat }\end{array}$} & $\mathrm{CO}(\%)$ & Y 1 & Kontinyu \\
\hline & & $\mathrm{HC}(\mathrm{PPM})$ & Y 2 & Kontinyu \\
\hline \multirow[t]{9}{*}{2} & \multirow{9}{*}{$\begin{array}{l}\text { Variabel } \\
\text { Bebas }\end{array}$} & Tahun produksi kendaraan bermotor & $\mathrm{X} 1$ & Kontinyu \\
\hline & & Teknologi kendaraan & $\mathrm{X} 2$ & $0=$ karburator \\
\hline & & & & $1=$ injeksi \\
\hline & & Perawatan Berkala & \multirow{6}{*}{$\mathrm{X} 3$} & \multirow{6}{*}{$\begin{array}{l}0=\text { tidak } \\
1=\text { ya }\end{array}$} \\
\hline & & $\begin{array}{l}\text { Penggantian oli kendaraan setiap } 5.000 \\
\mathrm{~km}\end{array}$ & & \\
\hline & & Penggantian filter pelumas/oli & & \\
\hline & & Pembersihan filter udara secara berkala & & \\
\hline & & $\begin{array}{l}\text { Pembersihan filter bahan bakar secara } \\
\text { berkala }\end{array}$ & & \\
\hline & & $\begin{array}{l}\text { Pelaksanaan servis sesuai dengan buku } \\
\text { petunjuk } \\
\text { Pelaksanaan servis berkala setiap } 6 \text { bulan } \\
\text { sekali }\end{array}$ & & \\
\hline
\end{tabular}

Tabel 2 Pengkodean variabel kendaraan berbahan bakar solar

\begin{tabular}{|c|c|c|c|c|}
\hline No. & \multicolumn{2}{|r|}{ Variabel } & Nama Variabel & Kode \\
\hline 1 & $\begin{array}{l}\text { Variabel } \\
\text { Terikat }\end{array}$ & Opacity $(\%)$ & Y 1 & Kontinyu \\
\hline \multirow[t]{9}{*}{2} & \multirow{9}{*}{$\begin{array}{l}\text { Variabel } \\
\text { Bebas }\end{array}$} & Tahun produksi kendaraan bermotor & $\mathrm{X} 1$ & kontinyu \\
\hline & & Teknologi kendaraan bermotor & $\mathrm{X} 2$ & $0=$ injeksi \\
\hline & & & & $1=$ common rail \\
\hline & & Perawatan Berkala & \multirow{6}{*}{$\mathrm{X} 3$} & \multirow{6}{*}{$\begin{array}{l}0=\text { tidak } \\
1=\text { ya }\end{array}$} \\
\hline & & Penogantian oli kendaraan setian $5000 \mathrm{~km}$ & & \\
\hline & & Penggantian filter pelumas/oli & & \\
\hline & & Pembersihan filter udara secara berkala & & \\
\hline & & $\begin{array}{l}\text { Pembersihan filter bahan bakar secara } \\
\text { berkala }\end{array}$ & & \\
\hline & & $\begin{array}{l}\text { Pelaksanaan servis sesuai dengan buku } \\
\text { petunjuk } \\
\text { Pelaksanaan servis berkala setiap } 6 \text { bulan } \\
\text { sekali }\end{array}$ & & \\
\hline
\end{tabular}

\section{ANALISIS DAN PEMBAHASAN}

A. Deskripsi Data

1. Hasil pengujian emisi gas buang untuk kendaraan wajib uji sebagai bagian dari uji berkala kendaraan bermotor. 
Dari hasil pelaksanaan penelitian terkait uji emisi pada sampel sebanyak 398 kendaraan, diperoleh data kendaraan yang lolos dan tidak lolos uji emisi sebagai berikut:

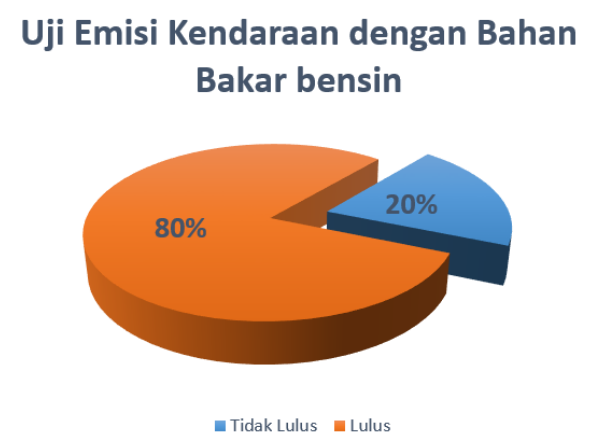

Gambar 2 Hasil Uji Emisi Kendaraan dengan Bahan Bakar Bensin

Dari Gambar 2 terlihat hasil pengujian terhadap 174 kendaraan dengan bahan bakar bensin didapatkan data sebanyak 139 (80\%) kendaraan lulus uji emisi dan sisanya 35 kendaraan (20\%) tidak lulus uji emisi.

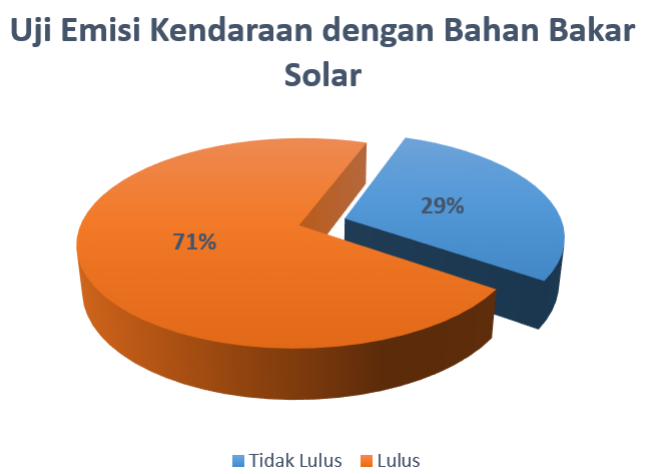

Gambar 3 Hasil Uji Emisi Kendaraan dengan Bahan Bakar Solar

Dari gambar 3 terlihat hasil pengujian terhadap 174 kendaraan dengan bahan bakar solar didapatkan data sebanyak 159 (71\%) kendaraan lulus uji emisi dan sisanya 65 kendaraan (29\%) tidak lulus uji emisi.

2. Hasil pengujian emisi gas buang berdasarkan teknologi suplai bahan bakar. Berdasarkan teknologi suplai bahan bakar kendaraan bermotor yang meliputi kendaraan berbahan bakar bensin, dengan teknologi konvensional (karburator) dan baru (injeksi), serta kendaraan berbahan bakar solar, dengan teknologi konvensional (injeksi) dan baru (common rail), diketahui sebagai berikut: 
Tabel 3 Hasil Uji Emisi berdasarkan teknologi suplai bahan bakar

\begin{tabular}{|c|c|c|c|c|c|}
\hline \multirow{2}{*}{ No. } & \multirow{2}{*}{\begin{tabular}{c} 
Hasil \\
\multirow{2}{*}{ Pengujian }
\end{tabular}} & \multicolumn{4}{|c|}{ Teknologi suplai bahan bakar } \\
\cline { 3 - 6 } & & \multicolumn{2}{|c|}{ Bahan bakar bensin } & \multicolumn{2}{c|}{ Bahan bakar solar } \\
\cline { 3 - 6 } & & Karburator & Injeksi & Injeksi & Common Rail \\
\hline 1 & Lulus & 45 & 94 & 93 & 66 \\
\hline 2 & Tidak Lulus & 21 & 14 & 45 & 20 \\
\hline \multirow{2}{*}{ Total } & 66 & 108 & 138 & 86 \\
\cline { 3 - 6 } & & \multicolumn{2}{|c|}{174} & & 224 \\
\hline
\end{tabular}

3. Hasil Pengujian Emisi Gas Buang berdasarkan Polutan

Berdasarkan polutan yang terkandung dalam emisi gas buang kendaraan bermotor yang meliputi Karbon Monoksida (CO) dan Hidro Karbon (HC) yang terdapat pada kandungan kadar emisi gas buang kendaraan berbahan bakar bensin, serta ketebalan asap (opacity) yang terdapat pada kendaraan berbahan solar, diketahui sebagai berikut:

Tabel 4 Hasil uji emisi gas buang kendaraan bermotor berbahan bakar bensin berdasarkan polutan

\begin{tabular}{|c|c|c|c|c|}
\hline \multirow{2}{*}{ No. } & \multirow{2}{*}{$\begin{array}{c}\text { Tahun } \\
\text { Produksi }\end{array}$} & \multicolumn{3}{|c|}{ Teknologi suplai bahan bakar } \\
\cline { 3 - 5 } & & $\begin{array}{c}\text { BO(\%) (rata- } \\
\text { rata) }\end{array}$ & $\begin{array}{c}\text { HC (PPM) } \\
\text { (rata-rata) }\end{array}$ & $\begin{array}{c}\text { Opacity (\%) } \\
\text { (rata-rata) }\end{array}$ \\
\cline { 3 - 5 } & & 5,77 & 1423,83 & 54,33 \\
\hline 1 & $1991-1995$ & 5,07 & 1348,00 & 58,00 \\
\hline 2 & $1996-2000$ & 4,11 & 919,63 & 60,88 \\
\hline 3 & $2001-2005$ & 2,21 & 447,71 & 69,16 \\
\hline 4 & $2006-2010$ & 1,21 & 285,86 & 51,60 \\
\hline 5 & $2011-2015$ & 0,61 & 191,42 & 41,25 \\
\hline 6 & $2016-2020$ & & & \\
\hline
\end{tabular}

B. Pengaruh Antara Tahun Produksi (Umur) Kendaraan, Tingkat Perawatan Kendaraan Dan Teknologi Mesin Untuk Suplai Bahan Bakar Terhadap Tingkat Emisi Gas Buang Kendaraan Bermotor Yang Dihasilkan.

1. Kalibrasi Model Kadar CO persamaan model dapat disusun sebagai berikut:

$$
Y=321,227-0.158 \times 1-1,535 \times 2-0,140 \times 3
$$


Keterangan :

$\mathrm{Y}=$ Kadar emisi gas buang $\mathrm{CO}$

$\mathrm{X} 1=$ Tahun Produksi Kendaraan

X2 = Teknologi suplai bahan bakar (karburator/injeksi)

X3 = Tingkat perawatan kendaran bermotor

2. Kalibrasi Model Kadar HC

persamaan model dapat disusun sebagai berikut:

$$
Y=39.291,548-695,253 \times 1-62,944 \times 2-18,989 \text { X3 }
$$

Keterangan :

$\mathrm{Y}=$ Kadar emisi gas buang $\mathrm{HC}$

$\mathrm{X} 1=$ Tahun produksi kendaraan (umur)

$\mathrm{X} 2$ = Teknologi suplai bahan bakar kendaraan bermotor (karburator/injeksi)

X3 = Tingkat perawatan kendaran bermotor

3. Kalibrasi Model Polutan ketebalan asap (Opacity)

Persamaan model dapat disusun sebagai berikut:

$$
Y=1.413,469-8,467 \times 1-13,506 \times 2-0,662 \times 3
$$

Keterangan :

$\mathrm{Y}=$ Kadar emisi gas buang (opacity)

$\mathrm{X} 1=$ Tahun produksi kendaraan (umur)

$\mathrm{X} 2$ = Teknologi suplai bahan bakar (injeksi/common rail)

X3 = Tingkat perawatan kendaran bermotor

C. Validasi Model

1. Uji Serentak Kadar CO

Statistik ujinya adalah sebagai berikut:

Tabel 5 Uji Serentak Kadar CO

\begin{tabular}{rrrr} 
& df & F & Sig. \\
\hline Model & 3 & 233,7447 & $.000 d$
\end{tabular}

Tabel 5 menunjukkan bahwa nilai $\mathrm{F}$ hitung $(233,744)>\mathrm{F}$ table $(2,656)$ bernilai 0,000 untuk semua parameter, maka dengan $\alpha(0,05)$ didapatkan keputusan tolak $\mathrm{H}_{0}$. 
Cara berikutnya adalah dengan penentuan koefisien determinasi $\left(\mathrm{R}^{2}\right)$ model seperti diperlihatkan pada tabel 6 dibawah ini:

Tabel 6 Koefisien determinasi model $\left(\mathrm{R}^{2}\right)$ Kadar CO

\begin{tabular}{|c|r|r|r|}
\hline $\mathbf{R}$ & R Square & Adjusted R Square & Std. Error of the Estimate \\
\hline .897 & 0,805 & 0,801 & 0,78185 \\
\hline
\end{tabular}

Dari Tabel 6 diperoleh nilai R-Square sebesar 0,805 yang artinya adalah variabel yang dimasukkan kedalam model berkontribusi 80,1\% terhadap kadar CO dan masih ada sekitar 19,9\% variabel lain yang belum di analisis

\section{Uji Serentak Kadar HC}

Statistik ujinya adalah sebagai berikut:

Tabel 7 Uji Serentak Kadar HC

\begin{tabular}{rrrr}
\hline & df & F & Sig. \\
\hline Model & 3 & 127,060 & .000 \\
\hline
\end{tabular}

Tabel 7 menunjukkan bahwa nilai $\mathrm{F}$ hitung $(127,060)>\mathrm{F}$ tabel $(2,656)$ bernilai 0,000 untuk semua parameter, maka dengan $\alpha(0,05)$ didapatkan keputusan tolak $\mathrm{H}_{0}$. Hal ini berarti bahwa parameter signifikan secara serentak/bersama-bersama atau model yang disusun mempunyai hubungan yang signifikan antara variabel bebas dengan variabel tidak bebasnya minimal ada satu variabel.

Cara berikutnya adalah dengan penentuan koefisien determinasi $\left(\mathrm{R}^{2}\right)$ model seperti diperlihatkan pada tabel 8 dibawah ini:

Tabel 8 Koefisien determinasi model $\left(\mathrm{R}^{2}\right)$ Kadar HC

\begin{tabular}{|r|r|r|r|}
\hline \multicolumn{1}{|c|}{$\mathbf{R}$} & \multicolumn{1}{|c|}{ R Square } & Adjusted R Square & Std. Error of the Estimate \\
\hline .832 & 0,692 & 0,686 & 289,675 \\
\hline
\end{tabular}

Dari Tabel 8 diperoleh nilai R-Square sebesar 0,692 yang artinya adalah variabel yang dimasukkan kedalam model berkontribusi 69,2 \% terhadap kadar HC dan masih ada sekitar 30,8\% variabel lain yang belum di analisis.

3. Uji serentak ketebalan asap (opacity)

Statistik ujinya adalah sebagai berikut: 
Tabel 9 Uji Serentak ketebalan asap(opacity)

\begin{tabular}{|r|r|r|r|}
\hline & df & F & Sig. \\
\hline Model & 3 & 166,258 & .000 \\
\hline
\end{tabular}

Tabel 9 menunjukkan bahwa nilai $F$ hitung $(166,258)>F$ tabel $(2,644)$ bernilai 0,000 untuk semua parameter, maka dengan $\alpha(0,05)$ didapatkan keputusan tolak $\mathrm{H}_{0}$. Hal ini berarti bahwa parameter signifikan secara serentak/bersama-bersama atau model yang disusun mempunyai hubungan yang signifikan antara variabel bebas dengan variabel tidak bebasnya minimal ada satu variabel.

Cara berikutnya adalah dengan penentuan koefisien determinasi $\left(\mathrm{R}^{2}\right)$ model seperti diperlihatkan pada tabel 10 dibawah ini:

Tabel 10 Koefisien determinasi model $\left(\mathrm{R}^{2}\right)$ Ketebalan asap (opacity)

\begin{tabular}{|c|r|r|r|}
\hline $\mathbf{R}$ & R Square & Adjusted R Square & Std. Error of the Estimate \\
\hline .833 & 0,694 & 0,690 & 11,2035 \\
\hline
\end{tabular}

Dari Tabel 10 diperoleh nilai R-Square sebesar 0,694 yang artinya adalah variabel yang dimasukkan kedalam model berkontribusi 69,4\% terhadap opacity dan masih ada sekitar 30,6 \% variabel lain yang belum di analisis.

\section{KESIMPULAN DAN SARAN}

A. Kesimpulan

Berdasarkan analisis dan pembahasan, maka dapat diambil kesimpulan bahwa hubungan antara variabel terikat dan variabel bebasnya adalahsebagai berikut:

1. Kendaraan dengan Bahan Bakar Bensin

a. Dengan perbedaan 1 tahun produksi kendaraan yang semakin baru akan menurunkan nilai kadar emisi gas buang CO sebesar 0,158 \%dan HC sebesar 695,253 ppm.

b. Dengan adanya perkembangan teknologi suplai bahan bakar kendaraan bermotor dari penggunaan karburator ke injeksi akan menurunkan nilai kadar emisi gas buang CO sebesar 1,535 \% dan HC sebesar 62,944 ppm.

c. Dengan adanya perawatan berkala pada kendaraan bermotor, akan menurunkan nilai kadar emisi gas buang CO sebesar 0,140 \% dan HC sebesar 18,989 ppm. 
2. Kendaraan Berbahan Bakar Solar

a. Dengan pengaruh tahun produksi kendaraan bermotor, akan menurunkan nilai kadar emisi gas buang opacity sebesar 8,467 \%.

b. Dengan adanya perkembangan teknologi suplai bahan bakar dari penggunaan injeksi ke common rail akan menurunkan nilai kadar emisi gas buang sebesar 13,506\%.

c. Dengan adanya perawatan berkala pada kendaraan bermotor, akan menurunkan nilai kadar emisi gas buang opacity sebesar 0,662 \%.

B. Saran

Adapun upaya yang dapat penulis sarankan atas hasil yang telah didapat dari penelitan ini adalah :

1. Perlu adanya langkah pemerintah untuk segera menerapkan pengujian berkala pada kendaraan pribadi guna pengawasan dan mereduksi pencemaran udara dari sektor transportasi seiring bertambahnya jumlah kendaraan bermotor.

2. Perlu adanya sosialisasi yang dilakukan pemerintah akan pentingnya perawatan kendaraan secara berkala sebagai salah satu langkah menjaga kelestarian lingkungan.

3. Dalam jangka panjang, perlu adanya kebijakan agar nantinya adanya penghapusan umur kendaraan bermotor, yang masih menggunakan teknologi suplai bahan bakar karburator pada kendaraan berbahan bakar bensin, serta coomon rail pada kendaraan berbahan bakar solar.

4. Dalam jangka panjang menerapkan kendaraan dengan alternatif penggunaan bahan bakar lebih ramah lingkungan, seperti kendaraan bahan bakar gas dan kendaraan listrik.

5. Peralatan pengujian yang dimiliki oleh seksi keselamatan pengujian kendaraan bermotor Kota Denpasar terbilang cukup canggih karena beberapa sudah digital dan berbasis computer. Namun hendaknya diwaktu mendatang dapat disesuaikan dengan teknologi kendaraan yang terus berkembang. 


\section{DAFTAR PUSTAKA}

Dinas Perhubungan Kabupaten Denpasar. 2018, Data Pengujian Emisi Gas Buang. Denpasar: Seksi PKB

Erwin.2006. Sumber polusi udara, Jakarta

Fardiaz, Srikandi. 1992. Polusi Air dan Udara. Bogor: Kanisius.

Harinaldi. 2005. Prinsip - prinsip Statistik Untuk Teknik dan Sains, Jakarta

Ilyas, M.2004. Mengatasi Emisi Melaui Perencanaan Sistem transportasi Perkotaan dan Kebijakan Pengendalianya. Bogor

Kementerian Perhubungan._1993. Keputusan Menteri Perhubungan Nomor 63 Tahun 1993 Tentang Persyaratan Ambang Batas Laik Jalan Kendaraan Bermotor, Jakarta

Kastiyowati. 2004, Akibat aktifitas perubahan manusia, udara seringkali menurun kualitasnya, Jakarta: Buletin Badan Litbang Kementerian Perhubungan.

Kementerian Lingkungan Hidup. 2006, Keputusan Menteri Lingkungan Hidup Nomor 05 Tahun 2006 Tentang Ambang Batas Emisi Gas Buang Kendaraan Bermotor Tipe Lama, Jakarta

Nasution, R. 2003.Teknik sampling. (serial online), [cited: 2016 feb 12]. Available from: URL: http://library.usu.ac.id/fkm/fkm-rozaini.

Pemerintah Daerah Pemprov Bali. 2007, Keputusan Gubernur Bali Nomor 8 Tahun 2007 Tentang Baku Mutu Lingkungan Hidup dan Kriteria Baku Kerusakan Lingkungan Hidup, Denpasar

Republik Indonesia. 2009. Undang - Undang Republik Indonesia Nomor 22 Tahun 2009 Tentang Lalu Lintas dan Angkutan Jalan. Sekretariat Negara Republik Indonesia. Jakarta.

Republik Indonesia. 2009. Undang - Undang Republik Indonesia Nomor 32 Tahun 2009 Tentang Perlindungan dan Pengelolaan Lingkungan Hidup, Sekretariat Negara Republik Indonesia. Jakarta.

Republik Indonesia. 2009. Peraturan Pemerintah Nomor 41 Tahun 2009 Tentang Pengendalian Pencemaran Udara, Sekretariat Negara Republik Indonesia. Jakarta. 